る水中養生中膨脹し車裂を生でた。

この水和作用を顕微鏡的に歓察すれば, A 組成の各 試料は焼結物では放射状, 六角板状結晶とゲル状物質 が認められた。熔融急冷物では塊状の一軸性結晶が, 失透物では針状結晶がよく発達していた。各試料はX 線と顕微鏡的に差異はほとんど認められなかつたにも か๖わらず，水和状況とルタル強度はかなりの差異
が認められた。次に B〜E 組成のガラスは，やはりは とんど水と作用せず， Bのみが7日後わずかに一部複 屈折性結晶を生成した。B〜E ガラスに刺㦸肪として $\mathrm{Ca}(\mathrm{OH})_{2}$ と $\mathrm{CaSO}_{4}$ を添加した場合は, 水和作用は よく進行し,カルシウムアルミノサルフェートを生成 した。

\title{
18. パラフィン被覆ポルトランドセメント
}

科學研究所 ○山根茂・谷田勇

ポルトランドセメントの凝結遅緩郕としては，ボル トランドセメントが寒用化されるに至つて以来今日に 至るまで，一般に石衰が使用されている。しかるに， 本邦では良質石高資源に乏しく，石高本来の用途にも 一部輸入に依存して抢り，セメント用には比較的品位 の低いるのがあてられているが，な扔一部は化学副産 石衰を使用せねばならぬ現状である。

すなわち，現在のところ石高を使用せずには実用的 なセメントは生廉でき奴状態にある。この研究は，石 高又は他のいわゆる緩結骩を使用せずに，烧塊粉末表 面を物理的処理することによつて緩結性とし, 且つ風 化にす耐えるようなセメントを得ようとするすのであ る。

その一つの試みとして，狫塊粉末を固体パラフィン の蒸気で処理して, その表面にパラフィンの薄膜を生 成せしめた。固体の溶解速度は一定条件の下では, 固 体表面の拡散層の厚さによつて支配せられるからこ の薄膜はセメントの溶解を遅める等である。パラフィ ン量をセメントに対し $0.01 〜 1.00 \%$ の閒に变化し， 処理温度をセメント工場に括ける烧塊粉䂶の際のミル 内温度を考慮して $100^{\circ} \rightarrow 170^{\circ} \mathrm{C}$ をで昷度を上年しなが らパラフィン蒸気で処理した場合, ヌパラフィンの量
を $0.1 \%$ に保ち，一定の温度 $\left(120,150,170,200^{\circ} \mathrm{C}\right)$ で 種々な時間処理した場合について，得られたものの， 凝結時間，強度，耐風化性等を調べた。これらの実験。 を通じて，多くの場合パラフィン量は $0.05 \%$ で十分 緩結性となり, 概して始登 3〜6 時間, 終結 5〜8 時 間を示し，市販セメントと比較して，より緩結性とな るか現行規格には十分合格する製品が得られる。パラ フィン量を増加し薄朝の厚さを増加すると凝結時間は 延長し，これに末処理焼塊粉を混用すると，逆に凝結 時間は短樎する。この未処理焼塊粉末添加量と凝結の 始発との間には直線関係が認められるから, 任意の始 発時閒をるつたセメントを得ることるできる。セメン ト粒子の表面に構成される薄膜の厚さは, 多くの場合 単分子層で十分であつて，その薄膜の存在の丽に耐風 化性も極めて大きくなるので, 取扱には安全となる。 砂入モルタルを練る場合には，気泡を抱込む性質があ り，AE 材と相似た効果が期待される。強度について は, 単分子層の形成に必要なパラフィンよりあ稍過量 のパラフイン量 $0.05 \sim 0.1 \%$ 添加したものの単純セ メントについては，石高 $3 \%$ 添加のそれに比較して特 に悪影響は認められず，28 日強度では 10\%程度の低 下を示したが，3 日強度はむしろ高い值を示した。

\section{9. セメント混合材の活性度評価試験法の研究（予報）}

\section{東京大学工学部広用化学科永井彰一郎・ $\bigcirc$ 真鍋 敏雄}

混合材を使う場合に最も重要なことは，如何なる混 合材をどら使つたならば，目的にかなりを耐久性のあ るコンクリートが得られるかといらことである。しか し, 一ロに耐久性といつてる, コンクリートの品質 は，その使われる場所によつて要求される要素が異な り，且つ混合材のセメント中に招ける反応機構にまだ 不明の点が多いので, 従来多くの研究者の関心が, 短
期間に行いらる混合材の評価方法に向けられ，種々の 方泆が試みられてきたにあかいわらず，充分確定的な 方法が得られていない。

その時々の異なる要求を一つの方法で評価すること は元来無理なことであるが, 混合材の反応機構の研究 と相俟つて, 数多くの実際的な試験を行つてゆけば, それらの要求との実験的相関性を簡単な方法によつて 
求めることる不可能なことではないであうう。

以上のような考えで, 従来試みられた方法を検討し つ〉, 更に新しい境地に進んでゆきたい積りで研究を 始めた。この報告には, その予報的な意味で従来の試 験方泆について比較検討のために行つた実験結果の二 三をのべる。

多珪酸質白土系の混合材について, 可溶分析試験, モルタル強度試験と Florentin 法により石灰と反応 した珪酸の測定を行い,一応モルタル強度を基準にし て比較検討した。

その結果は, (1)初期の 4 週までの強度は, 可溶分 析法による可溶珠酸量とほぶ一致するが, 長期の強度
は必ずしも一致しない。すなわち, 可溶珄酸の多いる のに 4 週以後の強度の発展がなく, 可溶理酸の少いる のに長期にわたる強度の発展が見られた。

（2）モルタル試験では普通 4 週までで止める場合 が多いが，かいる初期強度のみで混合材の評価をする ことは耐久性の点から危険である。

（3） $50^{\circ} \mathrm{C}$ 湿然養生した混合材一石灰混合物につい て, 石灰と反応した混合材中の珪酸量を Florentin 法により測定した結果は, モルタルの強度の発展性と 非常によく一致した結果を示した。今後多種の混合材 について検討すべき興味ある方法と思う。

\section{0. 焼石膏マグネシアセメントに関する研究}

\section{東京大学工学部応用化学科永井彰一郎・ $\bigcirc$ 福 森 康}

マグネシアセメントはその構成分の一つである軽焼 マグネシアの焼成温度により, 又も5一つの構成分で むる苦汁液又は塩化マグネシウム液の濃度により,こ れらの混練物から成るマグネシアセメントの硬化強度 についてみるに短期 1〜3 日の強度は大であつても, 1〜4 週の強度は低下寸る場合があるなど不安定であ り, 又耐水性が劣り, 水滴や空気中の湿気によつて表 面の光沢を失つたりするように, 種くの欠点があつて 多くの試験研究が行われている。

最近は,このマグネシアセメント用の軽焼マグネシ アが戦前のよらに鮮满からのマグネサイトの入手がほ とんど不可能なため, 印度・アメリカ・チェッコなど からマグネサイトを輸入することすら試みられるよう になつたが，寧ろ海水マグネシア法によつて水酸化、 グネシウムを製出し，これを軽焼マグネシアにして使 用する量が多くなつてきた。しかし, 海水直接又は鹹 水, 苦汁などに石灰乳を作用して水酸化マグネシウム を得る場合，極めて完備した方法により水酸化マグネ シウムを製出しないと，この水マグに炭酸石灰，硫酸 石灰などが混入して，この水マグのま〉又はこれを 焼成した軽焼マグネシアの中には炭酸カルシウム $\left(\mathrm{CaCO}_{3}\right)$, 硫酸カルシウムなどの形で混入し石灰分の 量が増してくると, このマグネシアはマグネシア・ク リンカー, マグネシア煉瓦などにして，各種製鋼，化 学工業用耐火煉瓦として不適当となり, 従つてこの軽 焼マグネシアの石灰問題は重大となつてくる。

マグネシアセメント用の軽焼マグネシアについて， この石灰含有量の問題は如何に考えられているか。演
者は，(1) 焼石膏とドロマイトとマグネシア，(2) ド ロマイトとマグネシアとの混合物に苦汁液を加えて, マグネシアセメントを試製して種々の硬化強度を試験 しても大差はないが, 特に注意したいのはこの軽焼、 グネシアに石灰の混入が多い場合，焼石膏とマグネシ アとの混合物を苦汁で湿捏して得られる特殊マグネシ アセメントに执ける石灰の影響如何の点であつた。

この石灰含有の軽焼マグネシアと苦汁とによるママグ ネシアセメントの試験で, 苦汁に硫酸マグネシウムを 含んでいるもの, 更に硫酸マグネシウムを少量加えた 苦汁液で混練したマグネシアセメントが，寧ろ強度の 優秀なことを認め，その説明にはこの石灰と硫酸マグ ネシウムの間に $\mathrm{CaO}+\mathrm{MgSO}_{4}+3 \mathrm{H}_{2} \mathrm{O} \rightarrow \mathrm{CaSO}_{4} \cdot 2 \mathrm{H}_{2} \mathrm{O}$ $+\mathrm{Mg}(\mathrm{OH})_{\mathbf{2}}$ のような反応で, 石高と水酸化、グネシ ウムを生じ, 苦汁との間に硬化を助けるためと考え た。この考えで, 更にマグネシアセメントに焼石高を 添加した硬化強度を試験寸るう向に進めたところ, 軽 焼マグネシアに焼石高を 3〜5\% 加えるだけで著しく 強度を増進して約 2〜3 倍となり, 殊に前述したマグ ネシアセメントだけは 1〜4 週䦎の強度の低下する不 安定性は, この烧石高の添加によつて全く一掃され, 寧ろ強度の増進を見るため, マグネシアセメントだけ の場合の 3〜4 倍の優れた強度にも達し, 焼石亳を增 して 10,15,20,25\% と多くしても強度は余り増進は しないが，やはり長期の不安定性は全く認められなか つた。文不灰含有の多いマグネシタセメントで,この 焼石高添加は何の害もなく, 苦汁に硫酸マグネシウム を少量含有するものを以つてすれば, 更に強度は改善 
されて優秀な結果を得た。

更に，この焼石高の少量添加によるマグネシアセメ ントは上記の優秀な硬化強度のみならず，硬化物は極 めて硬度が堅く, 緻密質で硝子のように破壊面子貝款 状を呈し，耐水性も優れ，湿気などで光沢を失うこと.
るなく，文硬化により膨脹収縮も極めて小さいことを 認めた。かように焼石市の 3〜5\% から 10\% の少量 を加えたマグネシアセメントの性状強度に著しい改善 を加えらる特殊の焼石高マグネシアセメントに関する 研究の予報的報告を行 5 のである。

\section{1. マダネシアセメントに関する研究（続報）}

\section{日本大学工学部 中原万次郎・ ○笠井 順一}

マグネシアセメントの主成分であるマグネシウムオ キシクロライドの化学式として多数の異る式が与えら れているが，その中で W.O. Robinson と W.H. Waggamanの再氏は $3 \mathrm{MgO} \cdot \mathrm{MgCl}_{2} \cdot 11 \mathrm{H}_{2} \mathrm{O}$ 、なる 式を, 又前田勉・山根茂両氏は $3 \mathrm{MgO} \cdot \mathrm{MgCl}_{2} \cdot 12 \mathrm{H}_{2} \mathrm{O}$ なる式を与えている。いま， $3 \mathrm{MgO} \cdot \mathrm{MgCl}_{2} \cdot 12 \mathrm{H}_{2} \mathrm{O}$ がマグネシウムオキシクロライドの正しい化学式を示 するのと考えてみるに，この配合がセメントの最適配 合を示すものでなく，実際には R. Zollinger 氏が示 したように8:1:15 の配合モル比が良いと報告され ているが, この配合に関する理論的考察の結果硬化七 メントの水分の脱出と吸着を考虑しない場合は，この 酣合を゙なくても，例光ば 4:1:10 文は 10:1:17の よ5な配合モ几比であ同程度むるいはそれ以上の強度 を出さなくてはならぬと考えた。すなわち

（1）マグネシアセメントで水和反心終了後に高強 度を出すためには，硬化物中に液相が存在しないよ5 にして，且つなるべく多くのマグネシウムオキシクロ ライドを含むよ5に配合すればよい。これらの関係を $\mathrm{MgO}-\mathrm{MgCl}_{2}-\mathrm{H}_{2} \mathrm{O}$ 三成分系化つき 三陆図表を作り その作図法を示し，如何なる配合が良いかを説明し， 且つ実験結果と理論的考察との結果が一致した。

（2） マグネシアセメントに招ける時効強度の原因 の一つは, 水和反応終了後に残存した液相が脱出する ことにより起るものであり, 又, 長期強度の減少する ことのあるのは，硬化物中に残存した未水和 $\mathrm{MgO} の$ “空中水分との反応によることと，硬化物中に液相の増
加する場合に起るものである。これらについて前記図 表から説明する。

(3) 以上の考えはマグネシアセメントに抽す 石灰の影響にも適用できるものである。すなわち, 、 グネシアセメントに石灰が混入した場合は，石灰が㙁 化マグネジゥム溶液と反応することにより塩化マグネ シウム溶液濃度の低下のために; 多くの場合硬化物中 の液相が増大寸る。“しかしながら，前記のように $\mathrm{MgO}-\mathrm{MgCl}_{2}-\mathrm{H}_{2} \mathrm{O}$ ，三成分系の配合理論に従い，石 灰が塩化マグネシウム溶液と反応しても，この反応に より変化したセメントの組成が理論水和量以下である ならば，不灰の影響は少い筈である。これらにつき実 験した結果について報告する。

又, 石灰が塩化マグネシウム溶液と全部反応して塩 化カルシウムになつたと仮定した場合のセメント組成 のものは, それと同一の $\mathrm{MgO}-\mathrm{MgCl}_{2}-\mathrm{H}_{2} \mathrm{O}$ の三成 分よりのみ成るセメントより強度が大であることから 考えて，不灰が塩化マグネシウム溶液と反応して全部 塩化カルシウムにならないるのと考光る。すなわち未 反応の不灰は恐らく $3 \mathrm{CaO} \cdot \mathrm{CaCl}_{2} \cdot 16 \mathrm{H}_{2} \mathrm{O}$ のようなカ ルの型でセメント硬化物に存在するものと考える。す なわち, 石灰の混入により起る凝結の促進と初期強度 の増加扣よび石灰の添加により起るかる知れない平衡 強度増加は, 石灰の水和熱と $3 \mathrm{MgO} \cdot \mathrm{MgCl}_{2} \cdot 12 \mathrm{H}_{2} \mathrm{O}$ の析出が平衡に達するまでに起る。第一次的な $\mathrm{Mg}(\mathrm{OH})_{2}$ の析出之 $3 \mathrm{CaO} \cdot \mathrm{CaCl}_{2} \cdot 16 \mathrm{H}_{2} \mathrm{O}$ の析出に もとずくものと考える。

\section{2. 焼石膏を配合した無水石膏の硬化}

\section{東京大学工学部応用化学科及綜合試験所永井彰一郎・ ○関谷 道雄}

建築用プラスター文は硬化物に使用される無水石望 に硬化性を附与する処理法について，各種の方法を 「無水石塝系プラスターの研究」第 1 報（䉑協, 56, (665)，525（昭 26)）に概述し，天然石高を種々の温
度て报焼脱水した無水石衰と副産無水石高について各 種の可溶性又は難溶性硬化成による硬化性を試験研究 した結果は既報（第 $1 \sim 2$ 報：不高研究会講演会，䀡 $26,10,27$ ，第 3 報：同講演会，眧 $27,5,27)$ の通りで 
ある。

今回は無水石高に硬化性を附与寸る処理泆の一つと して, 先に分類したB泆すなわぢ半水石高混合法につ いて比較試験した結果の一部を報告するるのである。 本研究に使用した無水石搞は岩手県岩沢鉱山産結晶 吕高粉を $400 ， 500$ 抢よび $1000^{\circ} \mathrm{C}$ に 30 分閒平衡报焼 し, 脱水調整したるのと，弗化水素製造時の副産無水 石高粉 2 種の 3 試料である。これに混合した半水石高 は履歷の異なる結晶石高を原料として製出されたるの 2 種と, 天然結晶石高塊を加圧水熱処理して製出され たもの 1 種の 3 種である。このよ5な無水石高と半水 石望を $3: 1,9: 1,19: 1$ の割合に混合し, 硬化調整剤 としては無水石高の硬化促進䏡に K-alum, $\mathrm{K}_{2} \mathrm{SO}_{4}+$

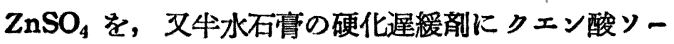
ダを使用しこれらの調整猎は予め別途に決定した所 要混水量の水に溶解して括き, 上記の混合した石高 $\left(x \mathrm{CaSO}_{4} \cdot \mathrm{Oaq}+y \mathrm{CaSO}_{4} \cdot 1 / 2 \mathrm{aq}\right)$ を湿合し，凝結時間， ルードゥイック式硬度による時効硬化度，耐王強度， 水和度等を測定し試験検討したのである。

この試験研究の結果を概述すると, 烺焼無水石高に ついて, 羡生条件（室内放置又は定期間湿空養生）に よる差異はほとんどなく，半水石高の配合率の高いほ ど初期硬度は大であるが，長期硬度と強度は小さくな る。又半水石高の履歴にはほとんど影響がないが，こ れからくる混水量 (J・E·S 篤業 1901) によつて混練 時の可塑性と併察して大きく硬度, 強度に影響され る。半水石亮の凝結遅緩は容易ではなく, 共存する無 水石高の硬化促進刘が同時に半水石高の促進刘になる ことから，凝䊅時間の調整が問題である。その他種各 結果を得たが, 又副産無水石高を試料とした場合, 上 記の烺焼無水石亳に拈ける傾向と異なるところがある。 が概して J.S. Dunn らの結果と異るよらである。

\section{3. 陶磁器の粉体成形に関する基礎的研究（第 1 報）}

\section{東京工大䇺業研究所 河島 千專・ ○村田 順弘}

䇺業では，粘土質原料を主体とした粉体の成形に関 寸る研究は極めて重要であるが，わが国ではまだ系統 的なまとまつた研究はされていない。本研究は乾燥粉 体の製造, 特に粘士質原料の噴霧乾燥の研究について, 主として実施したもので, その概略は次の通りであ る。"

噴霧による粉体の製造法としては一般に次の二つの 方法がある。

（1）遠心力を利用するもの。(2) 櫴射力を利用する ○。

本報告では前者すなわち沒漿を乾燥筒内で高速度回 転 (2 万回/分)による遠心力によつて吹き飛ばして粉 状とする方法を採用した。

その結果次のような事実が認められた。

(i) 粘土質の粉体はすべて球状を呈する。

(ii） 粘土粉体は吸水性の少い表面の平滑なるのが 得られた。

（iii） 粘土粒子の表面には微細なコロイド被膜の生 成が認められた。

(iv) 平坮粒径の等しいるのが多く得られる。

(v) 処理量, 収率と熱効率が予想以上に大である。

またこの装置の優れた利点として, 次の事柄を挙げ ることができる。

（イ）泥漿から直接操作によつて乾燥粉体が得られ
る。

（ロ）燥乾能率が良好で, 熱消費経済面, 特に一般 工場に㧈ける廃熱の利用法として極めて有利である。

(八) 乾燥は連続操作で, しかる短時間である。 装置に関しては次の点について研究したので, それ に関して述べる。

1. 加熱器一乾燥筒との関連について。

2. 送風口ノズルの形状について。

3. 噴霧乾燥機の構造について。

次に粉体の飛散状態とその分布について実験的結果 を検討し，一般に粒子は飛散距離と粒子数との関係が 正規型分布 (Normal Distribution) となることを指 摘し得たので, その詳細に関して述べる。

また回転子の形状が分散状態におよぼす影響につい て, 回転子内面の曲率と切为佣が粒子の飛散に如何な る影響を与えるか，それについて述べる。その城合， 分散は正規分布なので標準偏差と平均值等の做から, これらの物理的意味を実際の場合について検討して, 最も能率の良い回転子を指摘し得る。

次に分散粒子の大きさと飛散距離との関係につい:て 述べる。顕微鏡下の観察によると, この閒には淔線的 関係が成立する。しかし，粒子はある分布を有する が, この場合 $50 \mu \sim 350 \mu$ の分布となり, 特定位置に 执ける粒子分布の分布範网は約 $\pm 50 \mu$ であり, その 